\title{
AGAMA, SAINS, DAN COVID-19: MENDIALOGKAN NALAR AGAMA DAN SAINS MODERN
}

Hari-hari ini, perhatian umat manusia di seluruh dunia tertuju pada virus Korona yang mewabah di banyak negara sejak ditemukannya kasus wabah Korona di Tiongkok pada sekitar bulan Nopember - Desember 2019. Lembaga WHO (World Health Organization), sebagai Badan Kesehatan Dunia, menyatakan bahwa virus Korona atau Covid-19 (Coronavirus Desease 2019) merupakan pandemi yang telah merenggut nyawa ribuan orang.

Hingga pengantar ini dibuat tercatat di 34 propinsi, 34.316 orang dinyatakan positif, 12.129 sembuh dan 1.959 orang meninggal dunia (update 10 Juni 2020). Angka penularan yang begitu besar ini tidak hanya disebabkan oleh tingkat penularan virus yang begitu tinggi, tetapi juga diakibatkan minimnya pengetahuan serta pemahaman masyarakat kita terhadap penularan virus Korona (Covid-19) ini.

Berbagai otoritas kesehatan di seluruh dunia, mulai dari Pusat Pengendalian dan Pencegahan Wabah Amerika Serikat (CDC) hingga Badan Kesehatan Dunia (WHO) mengingatkan soal pentingnya tinggal di rumah selama penyebaran virus Korona masih terjadi. Sejumlah kalangan juga memberikan respons terhadap fenomena munculnya virus Korona ini, mulai dari kalangan pemerintah, ilmuwan dan agamawan. Pemerintah, misalnya, telah menetapkan PSBB (Pembatasan Sosial Berskala Besar) untuk memutus penularan Covid-19 di Indonesia. Upaya ini tidak lain adalah tindakan yang diambil berdasarkan riset dan fakta sains. beberapa kebijakan di antaranya adalah "merumahkan" para pelajar dan mahasiswa untuk belajar di rumah, menunda kegiatan-kegiatan yang melibatkan banyak orang, serta hal-hal lain yang sifatnya mengundang kerumunan massa.

Begitu pula langkah yang diambil oleh MUI (Majelis Ulama Indonesia) dengan mengeluarkan fatwa nomor 14 tahun 2020 tentang penyelenggaraan ibadah dalam situasi terjadi wabah Covid-19. Kurang lebih isi dari fatwa ini adalah instruksi peniadaan kegiatan keagamaan di masjid seperti sholat jum'at, 
sholat berjamaah dan kegiatan keagamaan lainnya pada daerah-daerah dengan tingkat penularan covid-19 yang tak bisa lagi dibendung. Nahdlatul Ulama dan Muhammadiyah, dua organisasi Muslim terbesar di Indonesia, juga menghimbau umat Islam agar tetap melaksanakan ibadah di rumah masingmasing. Namun, amat sangat disayangkan, masih banyak oknum yang memiliki idealismenya sendiri dan berseberangan dengan kebijakan yang diambil oleh pemerintah, maupun fatwa yang telah dikeluarkan oleh MUI.

Otoritas keagamaan secara serius telah memberikan edukasi yang benar kepada masyarakat dengan pandangan-pandangan keagamaannya, walaupun ada saja sebagian pihak yang malah melontarkan narasi keagamaan secara salah kaprah terkait fenomena virus Korona, misalnya, dengan mengatakan bahwa takdir kematian seseorang itu sudah ditentukan oleh Allah, dan tidak perlu takut kepada Korona karena yang harus ditakuti hanyalah Tuhan saja. Pandangan seperti ini-yang menyerah saja kepada "takdir Allah" (jabariyah), sehingga tak ada tindakan antisipatif terhadap Covid-19-kiranya dapat membahayakan orang lain. Sebab sikap tersebut menyebabkan mereka mengabaikan aturan kesehatan sehingga berpotensi tertular dan menularkannya kepada orang lain.

Apakah ini fenomena egoisme keagamaan, di mana umat beragama melakukan ibadah tanpa peduli dengan keselamatan manusia lainnya? Egoisme keagamaan tak lain dan tak bukan dipicu oleh sebuah anggapan yang kemudian pada masa tertentu telah mengental menjadi sebuah doktrin, dan kemudian memadat menjadi sebuah fanatisme yang terwujud dalam sebuah egoisme yang berbaju agama. Karena itu, kasus virus Korona ini seharusnya menjadi pelajaran untuk tidak dengan gampang menghakimi orang lain, apalagi dengan menggunakan ayat atau hadis yang ketika disampaikan oleh ulama yang dianggap kompeten dalam bidang agama kepada orang awam sebagai sebuah kebenaran yang tak terbantahkan.

Sejarah masa lalu dapat dijadikan pedoman umat Islam dalam bersikap proporsional menghadapi pandemi Covid-19. Rasulullah SAW mengajarkan apabila terdengar kabar valid mengenai adanya wabah penyakit yang sedang berjangkit di suatu negeri, maka kita dilarang memasuki negeri itu. Apabila telah ada yang terjangkit wabah, maka tidak boleh mencampurkan antara orang sehat dengan orang sakit. Umar bin al-Khaththab pun pernah membatalkan kunjungannya ke Syam karena telah terjadi pandemi penyakit di Syam saat itu. Dengan demikian, wabah penyakit itu tidak semakin tersebar luas dan penyebarannya dapat dibatasi. 
Di sisi lainnya, kemajuan sains dan teknologi ditantang untuk mengatasi dan menemukan obat mujarab penangkal virus Korona sehingga dapat digunakan untuk melakukan pencegahan melalui peningkatan imunitas tubuh-terlepas dari berbagai pendapat mengenai asal muasal secara pasti virus Korona dan beberapa teori konspirasi terkait penyebab kemunculannya.

Sebagaimana hasil riset dari berbagai ahli bahwa virus ini dapat ditularkan melalui droplet (Air Liur) dari sang penderita ataupun benda yang sudah terkontaminasi droplet, sehingga sangat penting menjaga jarak (Social Distancing) dengan penderita (carrier) untuk mengurangi resiko penularan dari virus ini. Menariknya, carrier dari virus ini belum tentu menimbulkan gejala klinis seperti sesak nafas, batuk, demam, pilek ataupun sakit tenggorokan, sehingga hal ini semakin menyulitkan kita untuk mengurangi potensi penularan dari sang penderita (carrier) Covid-19.

Orang-orang yang beragama dituntut untuk menyelaraskan antara keimanan di hatinya dan rasionalitas akalnya dalam menyikapi permasalahan kehidupan. Agama sifatnya transendental sedangkan ilmu pengetahuan bersifat empiris rasional yang dapat diuji kebenarannya. Ayat-ayat Al-Qur'an bersifat tetap, tetapi tafsirnya mengalami kontekstualisasi sedangkan kebenaran ilmu pengetahuan bersifat relatif. Sebuah teori masih dianggap benar jika belum ada teori baru yang membuktikan teori lama itu salah. Oleh sebab itu, dalam menghadapi Covid-19 umat Islam tidak hanya mengandalkan ritual saja apalagi terobsesi dengannya. Umat Islam harus bermula dari ritual lalu mempraktikkannya dengan cara-cara baik sesuai dengan anjuran ahlinya.

\section{Tentang Jurnal Ini}

Sejumlah artikel dalam jurnal edisi ke-36 kali ini telah memberikan banyak perspektif, untuk memperkuat etos keagamaan dan etos keilmuan. Juga, mampu melihat secara kritis dan otoritatif untuk membicarakan dua bidang wilayah, baik wilayah agama maupun ilmu pengetahuan. Pula, dapat mengurangi kesenjangan penafsiran di antara dua bidang yang semakin lama semakin terspesialisasi ini. Artikel-artikel dalam jurnal ini harus kita baca secara kritis guna melihat celah menyikapi Covid-19 dengan pendekatan integrasi agama dan sains sebagai paradigma penyelesaian krisis.

Artikel pertama oleh M. Amin Abdullah, menguraikan secara filosofis tentang hubungan agama dan ilmu pengetahuan. Argumen yang hendak diajukan oleh penulisnya bahwasanya hubungan antara agama, dalam hal ini 'Ulumu 
aldin (ilmu-ilmu agama Islam) dan ilmu, baik ilmu kealaman, sosial maupun budaya meniscayakan corak hubungan yang bersifat dialogis, integratifinterkonektif. Mendialogkan sisi subjective, objective dan intersubjective dari ilmu dan agama, menurutnya menjadi suatu keniscayaan dalam kehidupan multireligi-multikultural dan terlebih di era multikrisis yang melibatkan sains, kesehatan, sosial, budaya, agama, politik, ekonomi, keuangan sekaligus akibat penyebaran pandemi Covid-19 di dunia sekarang ini. Dan, kesemuanya itu tentu memerlukan upaya yang lebih serius untuk melakukan rekonstruksi metodologi studi keilmuan dan metodologi studi keagamaan di tanah air sejak dari hulu, yakni filsafat ilmu dan filsafat ilmu-ilmu keislaman sampai ke hilir, yaitu proses dan implementasinya dalam praksis pendidikan dan dakwah keagamaan.

Pada artikel kedua, Yordan Khaedir, mengajak para pembaca untuk melakukan penelusuran secara kepustakaan, guna memperoleh pemahaman secara benar mengenai karakteristik SARS-CoV-2, cara penularan (transmisi) virus, patogenisitas virus, manajemen kasus klinis dan aspek epidemiologi klinik Covid-19. Kajian riset ini diharapkan mampu memengaruhi pengambilan keputusan dalam rangka eradikasi Covid-19 dan kebijakan kesehatan masyarakat yang akan ditetapkan. Rekomendasi yang tepat dalam penanganan wabah dan perspektif masa depan Covid-19 juga diperlukan dalam menghadapi pandemi global Covid-19 ini. Dan, tak kalah pentingnya adalah strategi yang memiliki dasar sains, asas kesukarelaan, dan tanggung jawab sipil akan turut memberikan kontribusi dalam meningkatkan kepercayaan publik pada keseriusan pemerintah menangani pandemi.

Pada artikel ketiga, Musa Maliki, berusaha melihat konstruksi cara berpikir keberagamaan, khususnya Islam di masa pandemi Covid-19. Dalam menghadapi Covid-19 ini, penulisnya mengajak agar umat beragama menghayati agamanya dengan disiplin yang ketat, tidak serampangan dan melompat-lompat agar tidak terjebak pada discourse mempertentangkan agama dan sains. Karena itu, umat Islam harus memiliki pemahaman yang proporsional dan komprehensif atas keduanya sebagaimana dimiliki oleh para ilmuwan Islam terdahulu.

Artikel keempat, ditulis oleh M. Alkaf. Tulisan ini menjawab satu pertanyaan utama, tentang bagaimana agama memberikan perspektif mengenai wabah Covid-19, dan bagaimana hal itu dibicarakan dalam konteks hubungan agama dan sains? Studi ini menemukan bahwa selalu ada titik tengkar dan dialog antara sains dan agama di tengah usaha mendialogkan keduanya, seperti gerakan islamisasi ilmu pengetahuan, maupun dengan integrasi dan interkoneksi ilmu pengetahuan. 
Selanjutnya, artikel kelima, yang ditulis Abdullah Sidiq Notonegoro. Artikel ini mencoba melakukan pengamatan sederhana seiring adanya kebengalan politik pemerintah--baik pusat maupun daerah--yang meresponss setengah hati rekomendasi para dokter yang berada di garda depan pengobatan korban Covid-19 serta para virologi yang sedang berjuang untuk menemukan vaksin agar sebaran Covid-19 tidak semakin merajalela. Di sisi lain, keangkuhan sebagian elite agama yang menolak mentah-mentah ataupun setengah-setengah protokol pencegahan terhadap wabah Covid-19 tersebut.

Artikel keenam, yang ditulis oleh Falahuddin, secara serius membincang tentang peran Muhammadiyah dalam mengatasi wabah Covid-19 yang tidak hanya mengancam keselamatan jiwa manusia saja, tetapi juga telah memorak-porandakan sektor ekonomi dan sosial secara luas. Muhammadiyah telah berikhtiar secara maksimal untuk berkontribusi dalam penanganan Covid-19. Muhammadiyah telah membentuk semacam gugus tugas bernama Muhammadiyah Covid-19 Command Center (MCCC) yang menjadi garda terdepan dalam penanggulangan Covid-19 di Tanah Air. Muhammadiyah juga mendukung kebijakan-kebijakan pemerintah dalam menjalankan protokol kesehatan dalam rangka pencegahan penularan Covid-19, terutama terkait dengan pemberlakukan social/physical distancing.

Artikel ketujuh, oleh Haqqul Yaqin, mengeksplorasi secara kritis sains dan agama. Penulis artikel ini mencoba memadukan dua ranah yang selama ini dinilainya sangat dikotomistik. Agama dalam era nestapa manusia modern, yang ditandai dengan terjadinya krisis multidimensi, dituntut menunjukkan idealismenya dengan memberikan kontribusi-kontribusi praktik sosial yang lebih meneduhkan. Sementara, sains yang berpusat pada manusia dan kekuatannya dikembangkan untuk memahami diri dan agama serta hubungannya dengan sesama dan kedudukannya di alam ini.

Artikel kedelapan ditulis oleh Ahmad Muttaqin Alim. Dalam artikel ini, Ahmad Muttaqin secara filosofis menjawab pertanyaan bagaimana posisi ilmu kedokteran di dalam hierarkhi pengetahuan menurut para cendekiawan muslim; bagaimana perkembangan dunia kedokteran modern dan landasan filsafatnya, serta pekerjaan rumah para cendekiawan dan praktisi ilmu kedokteran bila ingin membangun konstruksi kedokteran Islam yang kokoh. Selanjutnya, pembahasan artikel ini mengerucut pada bagaimana seharusnya Ilmu Kedokteran Islam dipraktikkan dan dikembangkan saat ini dan saat mendatang. 
Pada artikel kesembilan, Iu Rusliana, berusaha menggali nilai-nilai normatif yang terkandung dalam ajaran Islam, kemudian memperkuatnya agar dapat menjadi peneguh sikap keberagamaan untuk melewati ujian pandemi Korona. Dalam artikel ini pula, penulisnya menjelaskan hubungan dialektis antara keimanan individual, sosial dan rasional dalam menghadapi pandemi Covid-19.

Artikel kesepuluh, ditulis oleh Mohammad Zaki Arrobi \& Amsa Nadzifah. Artikel ini berupaya menarasikan pandangan, sikap, dan peran otoritas keagamaan Islam dalam meresponss situasi pandemi akibat penyebaran virus Korona di Indonesia. Fokus artikel ini adalah artikulasi wacana keagamaan dan praksis sosial yang dilakukan oleh 'ustad selebritis' dan organisasi massa Islam dalam menghadapi pandemi akibat Covid-19. Tulisan ini mengulas pergeseran wacana di kalangan otoritas keagamaan menyangkut isu Covid-19.

Pada artikel kesebelas, Mush'ab Muqoddas Eka Purnomo, menjelaskan fakta empiris bagaimana kelompok kaum Islamis menggunakan agama sebagai dalih-dalih pembenaran. Hal ini dinilainya sebagai bencana kemanusiaan yang kemudian menjadi malapetaka. Tulisan ini adalah hasil riset yang menguraikan fakta bagaimana sikap kelompok kaum Islamis di Timur Tengah menghadapi pandemi, tentang fatwa ulama dan aksi-aksi teror di saat Covid-19.

Dan pada artikel terakhir, Wa Ode Zainab Zilullah Toresano, mengangkat tema mengenai "integrasi sains dan agama". Artikel ini berupaya untuk mengintegrasikan sains dan agama. Meskipun wacana yang ditawarkan pada tataran pemikiran, tetapi diharapkan bisa menjadi landasan bagi kaum agamawan dan saintis, terutama di Indonesia, agar bisa memandang wabah Korona ini dengan paradigma integralistik. Upaya integrasi sains [sains modern] dan agama dalam meresponss segala problem kemanusiaan, termasuk pandemi Covid-19, diharapkan dapat menjadi solusi, dan keduanya bisa memainkan peran yang sama dalam menyelesaikan wabah Korona ini.

Sebagai penutup kami berharap agar keduabelas artikel yang secara umum berbicara tentang Agama, Sains, dan Covid-19 ini dapat membuka jalan ke arah dialog yang lebih produktif untuk menghadapi tantangan kehidupan manusia di masa yang akan datang.

Selamat membaca.

Moh. Shofan

Pemimpin Redaksi Jurnal MAARIF 